\title{
Improving Grammar Mastery by Using Scramble Method of the Eleventh-Grade Students at Senior High School Number 2 Palopo
}

\author{
Andi Hasriani ${ }^{1}$, Masruddin ${ }^{2}$ \\ State Islamic Institute (IAIN Palopo), Indonesia \\ masruddin@iainpalopo.ac.id
}

\begin{abstract}
This research focused on using the scrambling method to teach grammar at the eleventh-grade students of Senior High School Number 2 Palopo. The research problem of this research was: "Does the scrambling method effectively improve students' grammar mastery?". The objective of this research was to find out whether or not the scrambling method effectively improves students' grammar mastery. In this research, the researcher used pre-experimental design, and the treatments were conducted in six meetings. The population of this research was the eleventh-grade students of senior high school 2 Palopo. The researcher used a total sampling technique. There were 26 students from IPA 3 class involved in this research. The instrument used to collect data was a written test. It was divided into pretest and post-test. The data of this research were analyzed quantitatively by using SPSS program version 20. The result of this research showed that the scrambling method effectively improves students' grammar mastery. The mean score in the pretest is lower than the mean score in the post-test $(63,85<82,23)$. The researcher found that the $p$-Value is 0.00 , and the alpha is 0.05 , therefore $p<\alpha(0.00<0.05)$. Meanwhile, the mean score of the post-test is better than the mean score of pretest $(82,23>63,85)$.
\end{abstract}

Keywords: English Language Teaching, Grammar Mastery, Scramble Method.

\section{INTRODUCTION}

In language learning, grammar is one of the main language aspects, especially in speaking and writing. To get good communication with other people, someone has to make the correct structure or grammar so that people do not misunderstand our speaking and writing (ESL, 2009). Grammar evolves both the use and the lack of human population. Formal grammars are a context of use developed by documentation over and over again, and with rules established and developed, prescriptive concepts of grammatical tenacity could arise. This often creates discrepancies between contemporary use and what has been adopted, over time, as the right thing. Grammar is a rule established in the English language itself. Formal grammar studies are an important part of education for children from a young age to advanced learning, although the rules taught in schools are not "grammar" in the sense that most linguists use the term, because they are often receptive and not descriptive (ESL, 2009). According to Rudy Haryono, Language is a means of communication, to communicate well, we must know about the grammatical language. Grammar is one of language learns about the way of arranging the word to become a sentence. So if we want to learn about the English language, also understanding grammar (Haryono, 2003). To write a sentence the students have to know about grammar. The common problem of English language grammar has to be overcome by all students, and the difficulties they find are similar in all part of the word. Flor and Jan Aarst says that grammars play an important part in the student's linguistic education. Apart from their role in language acquisition they form the basis on which the student's further, more theoretical, linguistic training can be founded. Students who have studied pedagogical grammars may be supposed to know English (Flor \& Aarts, 1982). Based on observation, the students in Senior High School 2 Palopo, especially in the eleventh class, there were still difficult to use the structure of grammar. Based on an exercise in 
the problems that have been given, they were having trouble working on that exercise. They had a problem in understanding how to compile words to form good sentences. Many students commonly make mistakes in grammar. Therefore, students need another method in grammar that can help them formulate good sentences. Scramble method would help found some mistake so it was processed to repaired became correct sentences. So the learning process took place in enjoying and interesting way.

\section{METHODS}

In this research, the researcher used the pre-experimental method. This method was used to know the effectiveness of the scramble method in teaching grammar at eleventh-grade students of senior high school 2 Palopo. The researcher took the population from the eleventh-grade students of Senior High School 2 Palopo in 2019/2020 academic year. Because the size of the population was petite so that the taking sample technique was total sampling. The researcher would examine the entire population that have a practical set of characteristics, they still had low achievement in grammar. The researcher took one class of the eleventh grade of Senior High School 2 Palopo as the sample, class IPA 3 which consisted of 26 students to be respondent in this research. They had the same proficiency level, they still had low achievement in grammar.

\section{The procedure of Data Collection}

The procedures for collecting data were described as follows:

\section{Pretest}

Before treatment took place, the class was given a pretest. The aim of pretest was to find out the students' prior knowledge in grammar.

2. Treatment

After giving pretest, the researcher treats the treatment through the scramble method, Each meeting has different material. The materials were introduced about the scramble method (scramble sentence and scramble discourse), and teach some kinds of tenses (simple past, simple present and simple future). The treatments consisted of four meetings.

\section{Post-test}

The post-test was given to the students after being taught and given the treatment. The purpose of post-test was to assess their achievement on grammar mastery.

\section{Instruments of the Research}

The tests were pretest and post-test. The purpose of the writing test was to know the students' level in grammar. The form of the test was to complete the paragraph by using the phrasing of words into a sentence.

\section{The technique of Data Analysis}

In giving scores to the students after following the pretest and post-test, the researcher adopted the scoring classification which is suitable with the grammar testing criteria. Those criteria or classification are presented as follows:

Table 3.2 Scoring classification using in grammar

\begin{tabular}{lll}
\hline No & Classification & Score \\
\hline $\mathbf{1}$ & Excellent & $96-100$ \\
$\mathbf{2}$ & Very Good & $86-95$ \\
$\mathbf{3}$ & Good & $76-85$ \\
$\mathbf{4}$ & Fairly Good & $66-75$ \\
$\mathbf{5}$ & Fairly & $56-65$ \\
$\mathbf{6}$ & Poor & $36-55$ \\
$\mathbf{7}$ & Very Poor & $0-35$ \\
\hline
\end{tabular}




\section{RESULTS}

The findings from the research were showed to describe the result based on the analysis of data collected. The researcher got the data by calculating students' pretest and post-test score.

The students' score of pretest and post-test result

Table 4.1 The students' in pretest and post-test result

\begin{tabular}{lccc}
\hline & & & Score \\
\cline { 2 - 3 } No & Students & Pretest & Posttest \\
\hline 1 & & 70 & 91 \\
2 & S1 & 65 & 91 \\
3 & S2 & 65 & 96 \\
4 & S3 & 70 & 75 \\
5 & S4 & 70 & 86 \\
6 & S5 & 65 & 84 \\
7 & S6 & 65 & 75 \\
8 & S7 & 65 & 75 \\
9 & S8 & 65 & 80 \\
10 & S9 & 55 & 75 \\
11 & S10 & 60 & 75 \\
12 & S11 & 55 & 83 \\
13 & S12 & 65 & 80 \\
14 & S13 & 60 & 75 \\
15 & S14 & 60 & 93 \\
16 & S15 & 60 & 80 \\
17 & S16 & 65 & 89 \\
18 & S17 & 70 & 82 \\
19 & S18 & 65 & 80 \\
20 & S19 & 65 & 80 \\
21 & S20 & 55 & 75 \\
22 & S21 & 60 & 85 \\
23 & S22 & 65 & 80 \\
24 & S23 & 65 & 80 \\
25 & S24 & 65 & 80 \\
26 & S25 & 70 & 93 \\
\hline & S26 & 1.650 & 2.138 \\
\hline
\end{tabular}

Table 4.2 The students' percentage in pretest and post-test result

\begin{tabular}{lccccc}
\hline \multirow{2}{*}{ Clarification } & \multirow{2}{*}{ Score } & \multicolumn{2}{c}{ Frequency } & \multicolumn{2}{c}{ Percentage } \\
\cline { 3 - 6 } & & pretest & posttest & Pretest & posttest \\
\hline Excellent & $96-100$ & - & 1 & - & $4 \%$ \\
Very Good & $86-95$ & - & 6 & - & $23 \%$ \\
Good & $76-85$ & - & 12 & - & $46 \%$ \\
Fairly Good & $66-75$ & - & 7 & - & $27 \%$ \\
Fairly & $56-65$ & 19 & - & $73 \%$ & - \\
Poor & $36-55$ & 7 & - & $27 \%$ & - \\
Very Poor & $0-35$ & - & - & - & - \\
\hline
\end{tabular}


Table 4.2 showed that there were 26 students observed in experimental class before giving treatment and after giving treatment. In the pretest, there were 7 students $(27 \%)$ who got a poor score, there were 19 students $(73 \%)$ who got fairly score. There was no student who got the excellent score, very good score, good score, fairly good score and very poor score. In the posttest, there were 7 students (27\%) who got a fairly good score, there were 12 students (46\%) who got a good score, there were 6 students (23\%) who got a very good score, and there was 1 student (4\%) who got an excellent score. there was no student who got fairly score, poor score and very poor score.

\section{The mean score of students' in pretest and post-test result}

Table 4.3. Mean Score of Students' in Pretest Result

\begin{tabular}{lcccccc}
\hline \multicolumn{7}{c}{ Descriptive Statistics } \\
\hline Pretest & N & Minimum & Maximum & Sum & Mean & Std. Deviation \\
Valid N (listwise) & 26 & 55 & 70 & 1660 & 63.85 & 4.540 \\
\hline
\end{tabular}

Table 4.3 showed that the highest score of students in pretest was 70 and the lowest score was 55 . Besides, it also indicated that the mean score in pretest was 63.85 , and the standard deviation was 4.54 .

Table 4.4 Mean Score of Students' in Posttest Result

\begin{tabular}{lcccccc}
\hline \multicolumn{7}{c}{ Descriptive Statistics } \\
\hline Posttest & $\mathrm{N}$ & Minimum & Maximum & Sum & Mean & Std. Deviation \\
Valid N (listwise) & 26 & 75 & 96 & 2138 & 82.23 & 6.489 \\
\hline
\end{tabular}

Table 4.4 showed that the highest score from students in post-test was 96 and the lowest score was 75 . Besides, it also indicated that the mean score in post-test was 82,23 , and the standard deviation was 6,48.

\section{The t-test Pretest and Posttest Result}

Table 4.5 below shows the possible value is better than alpha $(\alpha)(0.000<0.05)$. It means that $\mathrm{H}_{1}$ is accepted and $\mathrm{H}_{0}$ is rejected. It is concluded that there was a significant difference after treatment. It could also be stated the scramble method was effective to improve grammar mastery of the eleventh-grade students at senior high school number 2 Palopo.

Table 4.5 The Paired Sample Test of pretest and post-test

Paired Samples Test

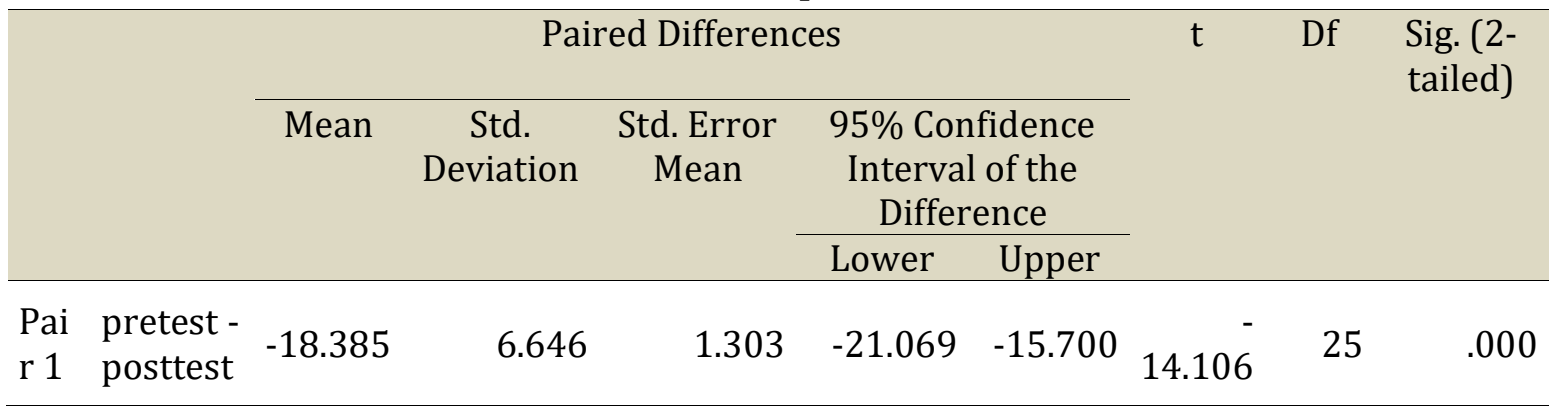




\section{DISCUSSION}

In this research, grammar test was given to the students that were still learning basic English, there was the class of IPA 3 at Senior High School 2 Palopo. Based on the result of data analysis of students' grammatical error in the pretest, the researcher found that students were still lack understanding of the worming structure correctly. The data that can be seen from the one that found the error is last "I not could sleep a night" should be "I could not sleep last night". Of the data, students have many mistakes in worming structure correctly. It means that the students did not remember or still lack of understanding about tenses so that students make mistakes in making a sentence. Based on the result of the data analysis shows that the scramble method is effective to improve the students' grammar mastery, it can be seen on the table before and after giving treatments continually (by using scramble method) the score of students' in pretest is 70 while the score of students' in post-test is 96 . It means that after giving treatment using scramble method is effective to improve the students' grammar mastery.

In this case, scramble method could attract the students in learning grammar mastery. Based on the research that had been conducted, during this research teaching grammar by using scramble method could make the students motivated to learn, they enjoyed and they were enthusiastic in the learning-teaching process. The students felt easier to write sentences or text by using the scramble method. It is evidenced that the scramble method could help the students to learn grammar. It has been discussed in Chapter II that Scramble is a rutting method that invites students to find answers and solve problems by handing out problem sheets and answer sheets along with available alternatives. Besides that, this research also in line with According to Robert B. Taylor scramble is one of the learning methods that can improve students' concentration and speed of thought. This method requires students to combine the right brain and the left brain. In this method, they not only asked to answer the questions but also to guess quickly answer questions that are available but still in random conditions (Huda, 2014). So that students can improve their grammar skill because students are trained to answer questions even in random form.

In fact, teaching grammar by using the scramble method at Senior high school number 2 Palopo, the students got better score grammar mastery. Therefore, it could be started that scramble method in teaching-learning of grammar has solved the students' grammar problem and increase the students' grammar skill for the eleventh-grade students of Senior high school number 2 Palopo. So, the hypothesis proposed in this research which says "the use of the scramble method is effective to improve students grammar mastery" is accepted. The similarities in the research of previous study and the researcher, they have used scramble method, they want to found out whether or not the scramble method was effective to improve students' skill in learning English. As for differences in the previous study and the researcher are in the previous study, they did research in SMP and MI, and they taught about writing skill. While the researcher did research in senior high school and taught about grammar mastery, focus on form/structure and meaning/semantics. The component of form/structure covers about an agreement with the genre of the text, and how it appears in certain literature, and pinning down the framework of a text, including the sequence of events, how they were told, and how they all fit together. The component of meaning/semantics covers of constructs a relation between adjoining words and clarifies the sense of a sentence, and literal or figurative.

\section{Conclusion}

The researcher concluded that the use of the scramble method is effective to improve grammar mastery of the eleventh-grade students at Senior high school number 2 Palopo. Based on the result from pretest and post-test, the maximum score in pretest is 70 , and the maximum score in post-test is 96 . The mean score pretest is 63,85 and the mean score post-test is 82,23 . It concluded that there was a significant difference in teaching grammar mastery before and after using the scramble method. 


\section{Suggestions}

From the conclusion above, there were some suggestions proposed by the researcher:

1. The teachers should be more creative in teaching and learning process to increase students' motivation in learning English.

2. The students have to be more active or have better motivation in teaching and learning process. The students have to pay attention to the teacher so that they can improve their grammar mastery.

3. The researcher appreciates that this thesis is still far from perfect words and because of that; upbuilding comments and advice are really expected for the perfection of this thesis. The researcher hopes that the result of this research can be useful for the readers. It is expected to the readers will get more information about interactive technical activities.

4. The researcher suggests the next researcher choose sentences or texts that can be easier to understand by students and give students more new vocabulary so as to increase students' knowledge.

\section{BIBLIOGRAPHY}

Afrizal, M. 2016 'Improving Students' Writing Skill by Using Scramble Sentence Method to the Second Years Students of SMP Negeri 3 Bireuen". Bireuen.

Agraini, Dewi Oktavia, 2017. Penerapan Metode Pembelajaran Scramble untuk Meningkatkan Hasil Belajar Bajasa Inggris Peserta Didik kelas III MI Thoriqul Huda Kromasan Ngunut Tulungagung.

Brown, Douglas, Teaching by Principles an Interactive Approach to Language Pedagogy, (San Francisco State University, 2001).

ESL.2009. "Teaching Grammar", Online: www.wikipedia.com. Accesses on October 10 2009.

Flor and Jan Aarts, English Syntactic Structures. (Pergamon Press 1982).

Huda, Miftahul, Model-Model Pengajaran dan Pembelajaran (Yogyakarta: Pustaka Belajar, 2014).

Komalasari, Kokom. 2010. Pembelajaran Kontekstual: Konsep dan Aplikasi. PT Refika Aditama. Bandung.

Kurniawan, Bella Aditya, 2016. "The Effectiveness of Scramble Method in Teaching Writing Procedure Text to the Seventh Grade Students At SMP Muhammadiyah 1 Purworejo in the Academic Year 2015/2016" Purworejo.

Muhajirah, M. (2020). Basic of Learning Theory: (Behaviorism, Cognitivism, Constructivism, and Humanism). International Journal of Asian Education, 1(1), 37-42. https://doi.org/10.46966/ijae.v1i1.23

Nisak, Rohmalia Dita Khoirun, "Pengaruh Mode Scramble Didukung Media Bagan Terhadap Kemampuan Memahami Kegiatan Jual Beli Di Lingkungan Rumah dan Sekolah Siswa Kelas III SD Mojoroto 1 Kota Kediri Tahun Pelajaran 2016/2017", (Artikel Skripsi Universitas Nusantara PGRI Kediri, 2017).

Nordquist, Richard, What is Grammar? (http://grammar.about.com) Accessed on 30th October 2011

Radford, Andrew. Transformational Grammar, (New York: Cambridge University Press, 1998).

Shoimin, Aris, 2013. 68 Model Pembelajaran Inovatif Dalam Kurikulum, (Yogyakarta: AR-RUZZ MEDIA, 2014). 